\title{
A Needs-Analysis-Based Survey of the Curriculum Design for Undergraduate Translation Majors: Exemplified by Qinghai Normal University
}

\author{
Tianlu Ji \\ Institute for Qinghai Normal University, Xining, China \\ Email: 327331823@qq.com
}

How to cite this paper: Li, T. L. (2021). A Needs-Analysis-Based Survey of the Curriculum Design for Undergraduate Translation Majors: Exemplified by Qinghai Normal University. Open Journal of Modern Linguistics, 11, 555-565.

https://doi.org/10.4236/ojml.2021.114042

Received: July 2, 2021

Accepted: July 26, 2021

Published: July 29, 2021

Copyright (อ 2021 by author(s) and Scientific Research Publishing Inc. This work is licensed under the Creative Commons Attribution International License (CC BY 4.0).

http://creativecommons.org/licenses/by/4.0/ (c) (i) Open Access

\begin{abstract}
In recent years, the bachelor of Translation and Interpreting (BTI) programs are flourishing in China. Needs Analysis has emerged as a powerful tool in studying the curriculum design. As the first university in Qinghai province that started BTI program, Qinghai Normal University undertakes the important task of cultivating local translators and a scientific curriculum design has a pivotal role in the process. This study sets out to determine whether the current curriculum can effectively meet the students' needs and the social needs and provide suggestions on curriculum design. An online survey provided quantitative data from 102 participants, involving students, translators and administrators from government sectors, foreign trade companies and translation companies. Evidence is presented which shows that students' learning needs are satisfied to a large extent but there is still potential for improvement of the current curriculum.
\end{abstract}

\section{Keywords}

Curriculum Design, Needs Analysis, Translation Major, Questionnaire

\section{Introduction}

Since 2006, the Ministry of Education has piloted the Bachelor of Translation and Interpreting (BTI) programs at Fudan University, Guangdong University of Foreign Studies and Hebei Normal University. After that, there is an increasing number of universities in China offered BTI degrees. So far, there have been 272 universities that have set BTI programs and they are constantly exploring and 
improving the talent training plan, curriculum system and evaluation system. As the only university in Qinghai province that started BTI program, Qinghai Normal University undertakes the important task of cultivating local translators. Only a reasonable curriculum can meet the needs of the local market and ensure the employment in the professional field. In addition, a scientific curriculum design would improve the professional skills of students, which will inevitably help to prosper the translation market and improve the level of foreign exchanges and cooperation in Qinghai Province.

Needs analysis is fundamental to formulate foreign language education policies. If curriculum designers ignore needs analysis, the curriculum might mislead teaching and be hard to satisfy the needs of society and students. According to Chen (2010), needs analysis has become an indispensable starting step when a foreign language course was set, because the results of need analysis could help teachers make teaching goals, syllabus and specific teaching plans with clear purposes. The curriculum setting should not be linear or static, but it is a continuous and intermittent process inserting in every stage of a course, including curriculum setting, curriculum implementation, curriculum adjustment, and curriculum evaluation, which help students and teachers to identify new needs and play an important role in evaluating and giving feedback. The on-going needs analysis always serves to meet the changing learning needs of students and the established teaching goals.

The objective of this study is to investigate whether the current curriculum of BTI in Qinghai Normal University is reasonable enough to both satisfy the students' needs and the social needs and provide effective suggestions on curriculum design. Questionnaire and interview were adopted in this research, which involved 70 students from Qinghai Normal University and 32 employers from government sectors, foreign trade enterprises and translation companies.

\section{Literature Review}

In 1978, Munby (1978) proposed Target Situation Analysis, focusing on the gap between students' target needs and their current ability, but it was just a partial and preliminary needs analysis that could not be used into curriculum design. Later, Hutchinson and Waters (1987) put forward the Needs Analysis Model based on Target Situation Analysis. They believe that needs could be divided into target needs and learning needs. More specifically, target needs involve necessities, lacks and wants while learning needs include learning conditions, skills, strategies, knowledge, motivation and time, etc. The Needs Analysis Model integrated both target needs and learning needs, which is a great leap from Target Situation Analysis, but it lacks the identification of students' deficiency. Perhaps the most thorough account of needs analysis model is that of Dudley-Evans and St John (1998), covering 7 aspects such as student professional information, personal information, and language information. They point out that target demand or social demand is an aspect that cannot be ignored in the analysis of talent 
demand, which reduced the arbitrariness in the process of curriculum design and implementation, so it could be used as a basis for deepening the reform of foreign language education.

In recent years, BTI programs have developed rapidly in China, but because it started late, the curriculum of translation majors could be described as vastly different. Scholars and experts have not yet reached a consensus, but there have been considerable research on curriculum of translation majors, which are mainly divided into three categories. Firstly, from the perspective of the relationship between curriculum and the training of applied talents, some researchers regard improving students' translation ability as the core of the curriculum (Li, 2010); Zhu and Yang (2019) suggest that the training for China Accreditation Test for Translators and Interpreters (CATTI) should be embedded in the curriculum. Secondly, from the perspective of the relationship between local development and curriculum setting, Teng and Zhang (2013) explore how to make the curriculum serve the local economic development and Wang (2010) discusses how to develop a localized training model. Thirdly, from the comparative perspective of translation curriculum at home and abroad, Li (2018) interpreted the curriculum for the undergraduate translation major of University of Otawa in Canada, pointing out that the talent cultivation objective should be set as training universal specialized talents.

In the west, especially in countries where English is the mother tongue, society has a huge demand for translators. From undergraduate, master to doctor, the translator and interpreter training system has been very complete. The courses offered are mainly divided into three modules: translation practice and theory, general education and bilingual skills. The focus of research on the curriculum is mainly focused on the proportion of the three modules (Beeby, 2000), the correct handling of the relationship between interpretation and translation courses (Agrifoglio, 2004), and the construction of characteristic translation courses (Kiraly, 2000).

In short, although there has been considerable research on the curriculum setting for undergraduate translation majors, little of them used needs-analysis-based survey that is very practical to guide the reform of the curriculum to find out the gap between the current curriculum and the needs of students and society. To date, there has been no reliable evidence to prove the rationality of the curriculum for translation majors in Qinghai Normal University.

\section{Research Procedures and Discussion}

\subsection{Research Objectives}

According to needs analysis model, both learning needs and social needs should be considered when universities design curriculum. Thus, the research aims to investigate whether the current curriculum for undergraduate translation majors in Qinghai Normal Universities has satisfied the needs both of students and the society and try to answer the following questions: 
1) How do students evaluate the status and effectiveness of the teaching of translation majors? Could their learning needs be met?

2) How do the employers think about curriculum for translation majors? Could their demands for talents be satisfied now?

3) How to optimize the current curriculum designs if they do not adequately reflect social needs or students learning needs?

\subsection{Research Participants}

As Table 1 shows, there were 70 students who graduated from or are studying in the translation major involved in the students' needs survey, and 15 of them were randomly chosen for later interviews to add some details and help the researcher get a better understanding of questionnaires. The subjects for social needs analysis were 5 professional translators, 10 human resource managers and 17 administrators in companies or government units in Qinghai province, including Foreign Affairs Office of Qinghai Province, Department of Commerce of Qinghai province, Qinghai University Affiliated Hospital, Department of Security of Qinghai province, BYD Auto Co. Ltd in Xining, the People's Bank of China Xining Central Sub-branch, Xining Development and Reform commission, etc.

The questionnaire for students' need analysis was divided into three parts, personal information (current jobs or future plans), curriculum satisfaction (including 31 courses) and suggestions. The questionnaire for social needs analysis comprising 6 questions, fell into three categories, current translators' conditions in the work unit, the most needed qualities of translators, expectations and suggestions. After that, face to face or online interviews were randomly conducted to some respondents of each group, aiming to receive more details about questionnaires and know more about their specific needs.

\subsection{Discussion}

\subsubsection{The Approbation and Learning Needs Analysis of Curriculum Design for Undergraduate Translation Majors}

In terms of students' satisfaction with curriculum of BTI, it could be said that more than half of students held a positive attitude towards current curriculum which was relatively reasonable. However, there was still large room for optimization. More specifically, $27.14 \%$ of students thought that the curriculum had satisfied their needs a lot and $48.57 \%$ of students believed that their study needs

Table 1. Information of the participants.

\begin{tabular}{cc}
\hline Groups of Participants & Number \\
\hline Students of translation and interpretation major in Qinghai Normal University & 70 \\
Government Units & 20 \\
Translation Companies & 5 \\
Foreign Trade Companies & 7
\end{tabular}


could be basically satisfied. Students who thought the curriculum was not bad but just normal accounts for $22.86 \%$. The number of students who were not satisfied with the translation curriculum was zero, and only $1.43 \%$ of the students believed that the curriculum was completely unable to meet their learning needs. The results, as shown in Figure 1, indicated that the overall response to the curriculum was positive and a minority of participants indicated that there were still needs for reform.

This questionnaire also surveyed students' demand for 31 specific courses offered by Qinghai Normal University's translation major. From Figure 2, it could be seen that the most needed course of students was translation, followed by comprehensive English, interpretation, listening and translation and translation of current affairs. The least needed course was language testing, followed by editing and translation of news, Chinese, translation of poetry and computer aided translation (CAT).

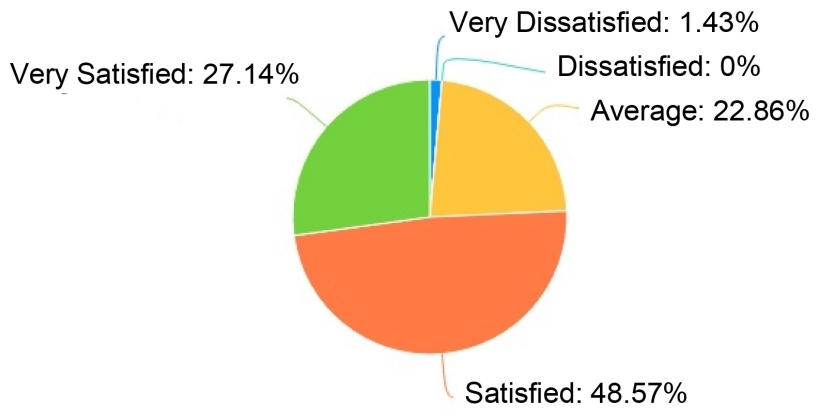

Figure 1. Students' satisfaction with curriculum of BTI.

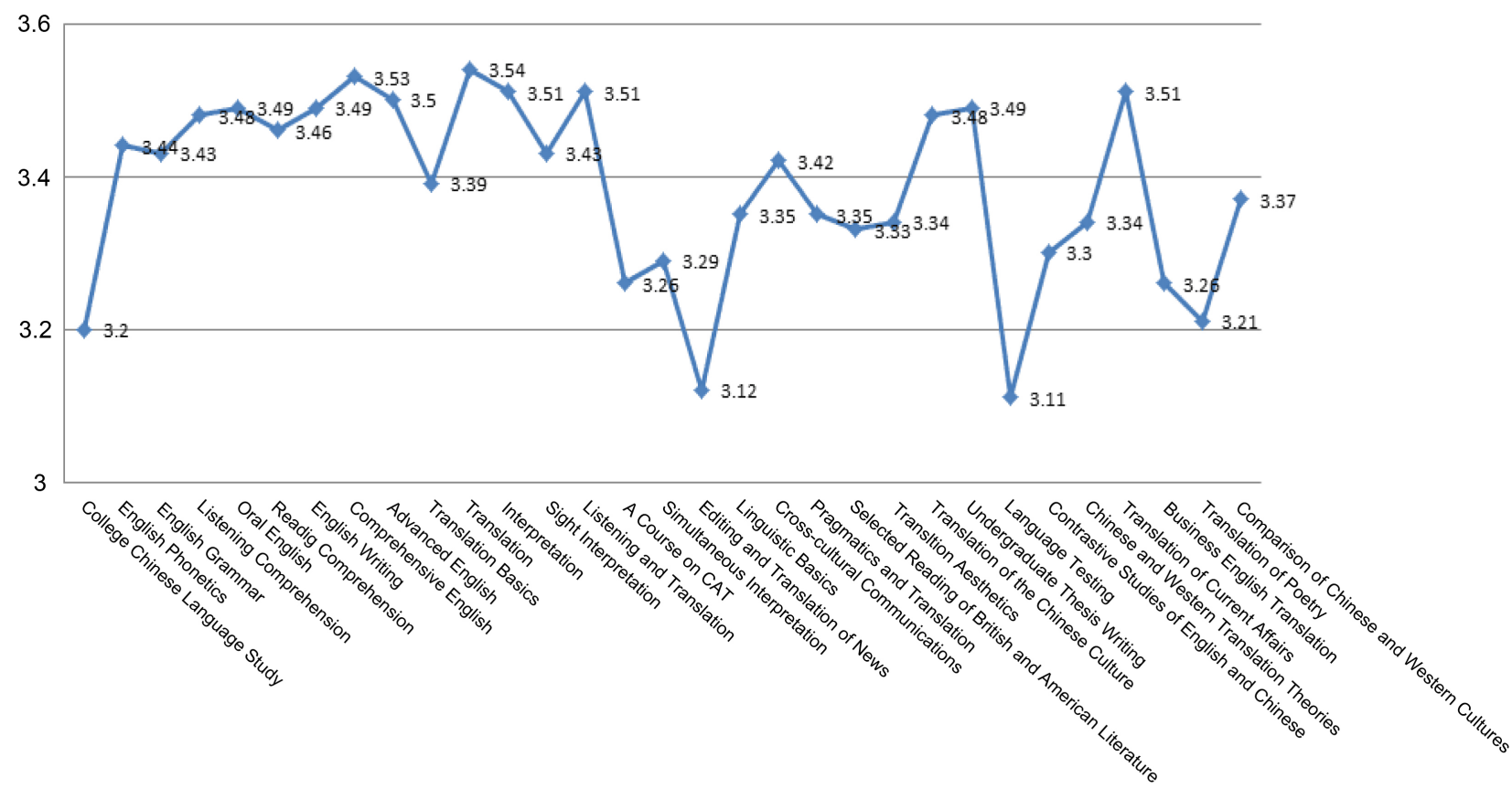

Figure 2. Students' demand degree for courses. 
The results of questionnaire showed that students had the highest demand for the courses of basic translation skills, such as translation and interpretation. Courses on English basic ability were also needed, like comprehensive English, listening and oral speaking. What was unexpected was that the demand for courses of specialized translation was not as high as predicted, such as editing and translation of news, translation of poetry, CAT and simultaneous interpretation.

Through follow-up interviews, the author learned that some students held the idea that the setting of some courses ignored the local employment situation and the real language ability of students. If students did not lay a good language foundation in the lower grades, it would be very difficult for them to learn translation professional courses in senior grades, which was the reason that students thought there was no need to offer simultaneous interpretation. In addition, students also put forward that some courses were not in line with local job market which meant that they thought there was little use for them to learn. For example, CAT was an essential skill of professional translators but there were few mature translation companies or translation projects in Qinghai so that students had little interest in this course. Conversely, most of students showed their urgent desire for the increase of the class hour of translation and interpretation courses. They insisted that translation and interpretation courses should be offered ever semester from the first year to senior year.

\subsubsection{The Social Needs Analysis of Translation Talents and Curriculum Design}

Figure 3 indicated the distribution of majors studied by translators and interpreters in their institutions or companies, which was a pity that translation and interpretation majors only accounted for $3.12 \%$. The largest proportion was occupied by English-related majors, and many of translators and interpreters graduated from other majors. Combining the survey of students' learning needs, the author found that most graduates of translation and interpretation majors were not engaged in translation industry while most people working in the industry in Qinghai were not translation majors. That is to say, a huge gap is existing between the training of undergraduates of translation and interpretation majors and the job market. The curriculum design might be not in line with the social needs, which reflected the necessity and urgency of curriculum reform.

From Figure 4, it could be clearly shown that approximately $85 \%$ of translators, administrators and HR managers thought the most important ability of professional translators and interpreters was English proficiency while when they were asked which aspects should be strengthened the most in the curriculum, up to $90.63 \%$ of them also voted to English language competency (Figure 5). The choice of translation skills also ranked high in both of the two bar graphs. These results coincided with the findings of students' learning needs survey, which once again demonstrated that it was vital for students of translation and interpretation to be equipped with a high level of English language 


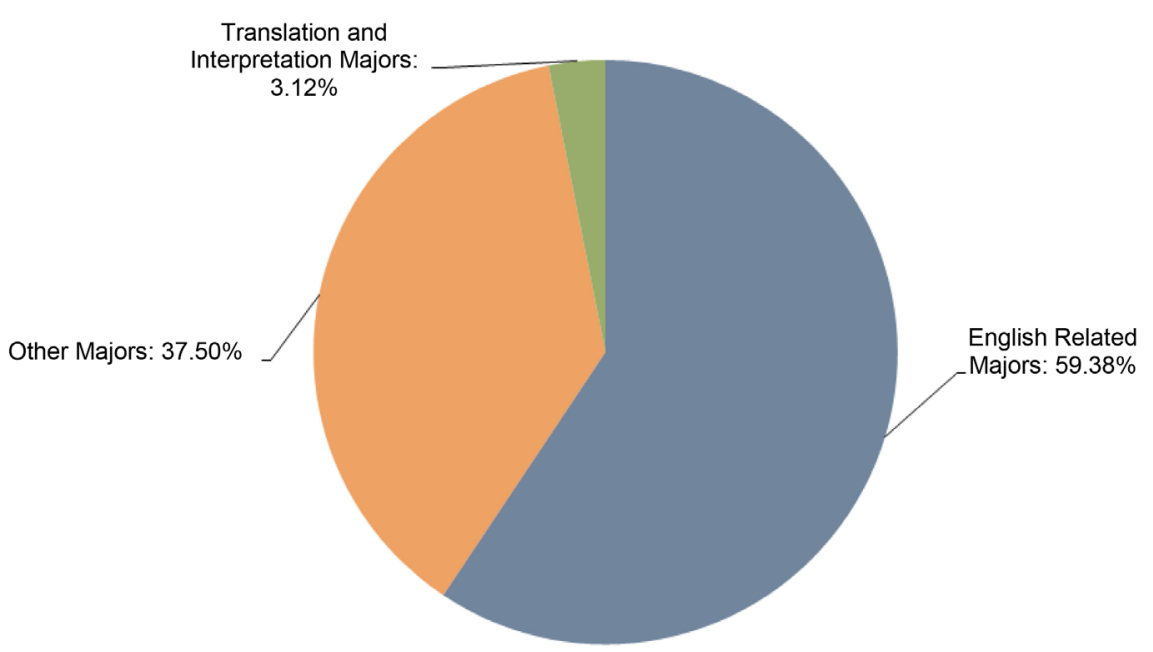

Figure 3. Undergraduate majors of translators and interpreters.

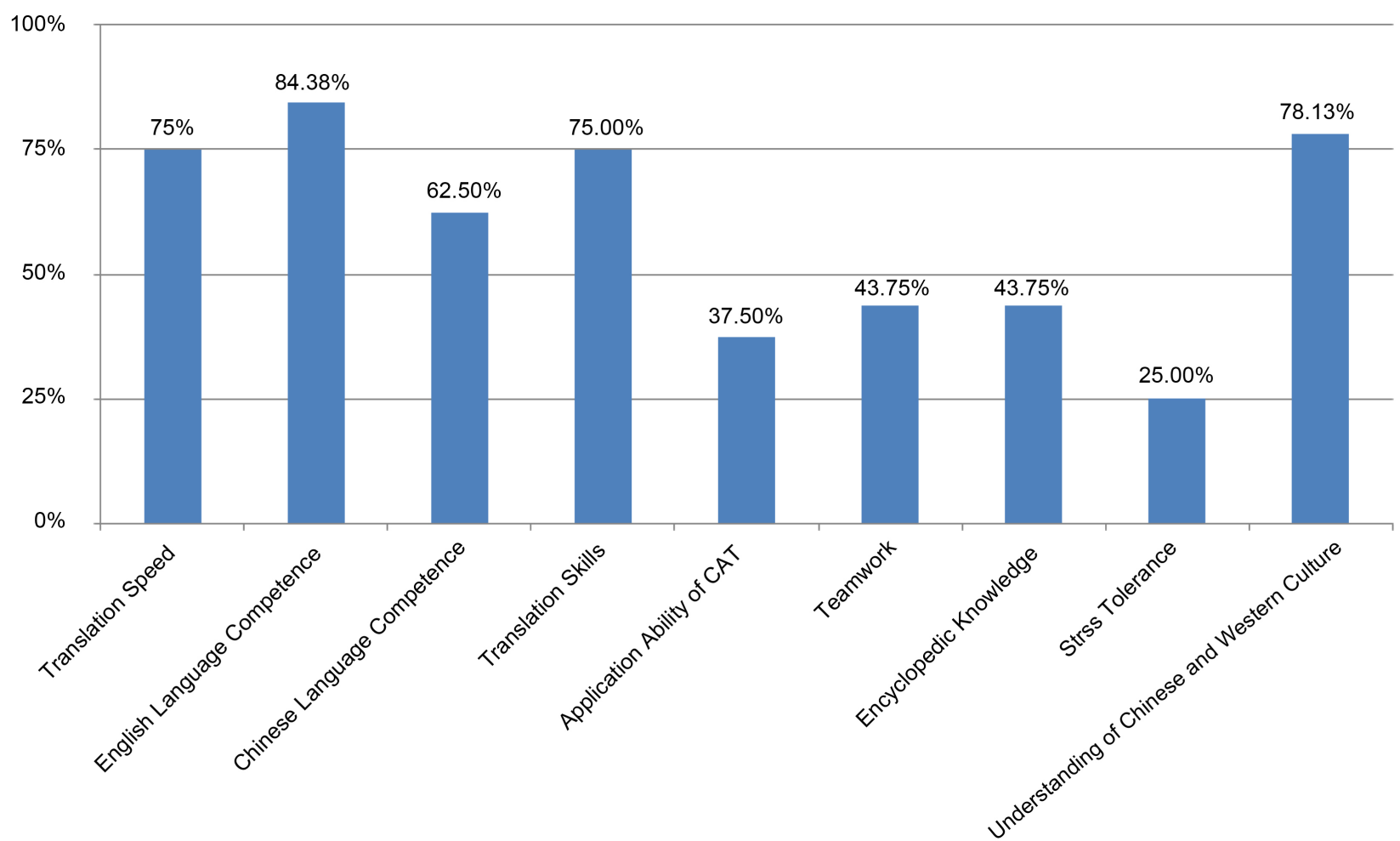

Figure 4. Most important ability requirements for professional translators.

competency. The author interviewed an administrator in the Foreign Affairs Office of Qinghai Province and he said that the undergraduate training of translation majors should still focus on the training of basic language capabilities and translation skills. At the undergraduate stage, the key mission was to lay a solid language foundation, specially for universities like Qinghai Normal University, because the English level of students when they were enrolled was not as advanced as students in eastern developed cities. Therefore, some advanced courses like specialized translation and computer-aided translation could be put 


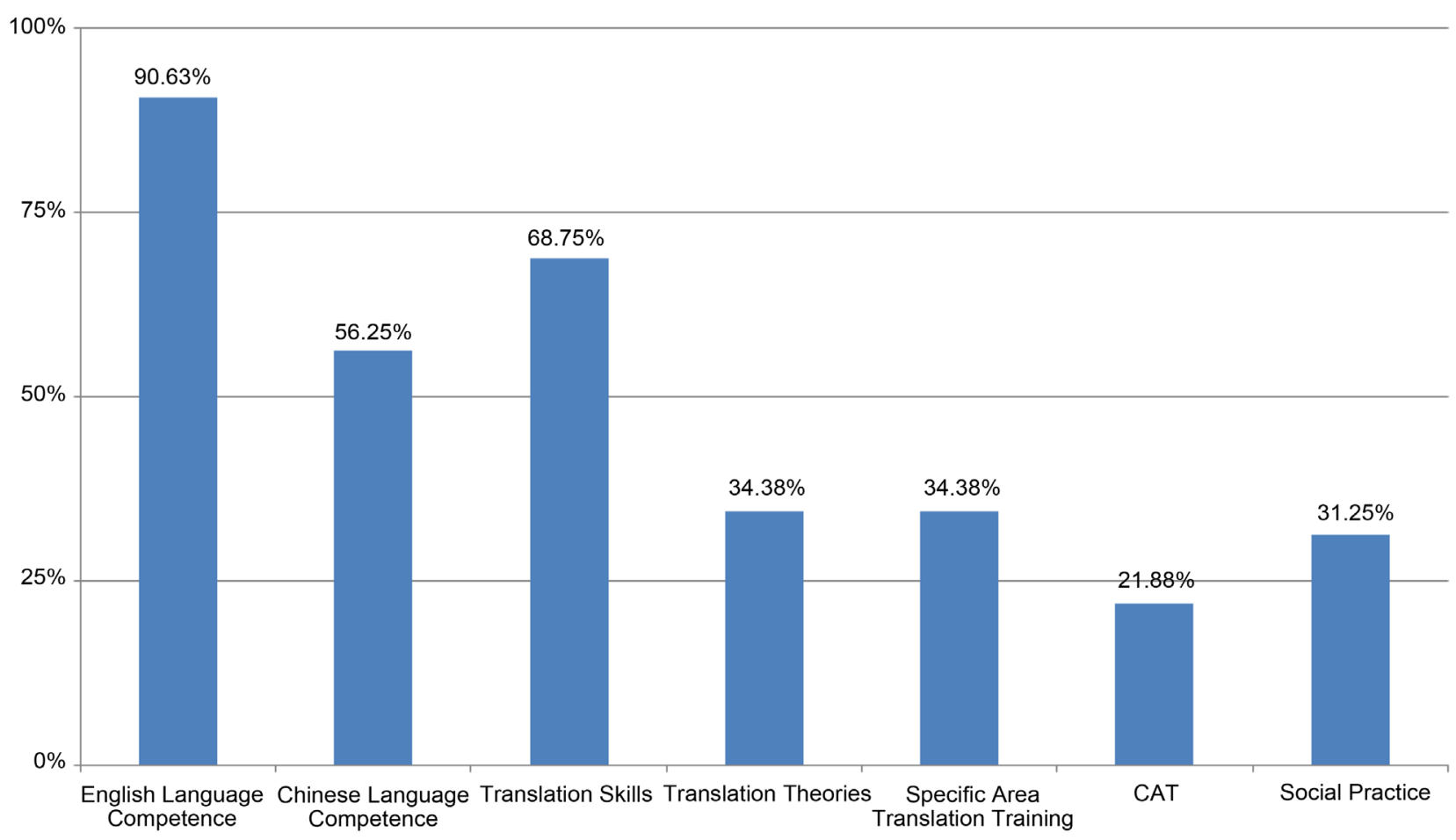

Figure 5. The aspects should be strengthened the most in the curriculum of translation interpretation majors.

to the graduate stage. In addition, unlike postgraduate education, the curriculum for undergraduates should be broader to cope with the uncertainty of future positions.

\section{Suggestions}

\subsection{Increasing the Proportion of Practical Courses}

Together these results illustrate urgent needs for practical courses, both from students' needs analysis and social needs analysis, involving translating and interpreting skills. Given that the translation and interpretation related activities are highly practical and job markets put a lot emphasis on students' practical capability, the curriculum design should involve more practical teaching. Practical courses could be divided into on-campus practice and off-campus practice. In offcampus practice, universities can make attempts on the cooperation with enterprises or selecting students to participate in translation activities in the province, like some international sports events, exhibitions and conferences, etc. Thus, students can apply what they have learned in the school and experience the real translating process. In terms of on-campus practical courses, teachers of translation and interpretation majors could establish translation and interpretation workshops and select suitable materials for students to conduct exercises in groups. Later, feedback and guidance will be given by their tutors.

\subsection{Strengthening the Construction of Teaching Staff}

In terms of teaching staff, there is a consensus in the field of translation, which is 
that qualified translation teachers should not only grasp the translation theory system, but also have rich translating and interpreting experiences and be familiar with the operation of the translation industry. That is to say, teachers of translation and interpretation majors should have completed a certain number of translation tasks or interpreted in a certain number of meetings or other interpreting activities. Only when they have experienced the process of translation and interpretation can they become confident in explaining how to translate or interpret. Besides, teachers should master the modern teaching techniques and methods of foreign language. Frankly speaking, the current teaching staff of Qinghai Normal University's translation major still need to be improved. Although the teachers are all graduated from translation or interpretation majors and hold master's or even doctoral degrees, few have working experience in the translation industry. To tackle this problem, two methods are provided as below. Firstly, the university should attach great importance to the training of teachers to improve their professional competence. In addition to upgrade their education degrees, universities could send teachers to the front line of translation through cooperation with enterprises to help teachers gain working experience and improve their understanding of the translation industry, thereby promoting the effectiveness of classroom teaching. Secondly, universities could hire experts in the language service industry as part-time teachers, such as professional translators, interpreters, revisers, editors and managers of translation companies. With rich and vivid experience in the industry, they can teach some professional courses. Only a two-pronged strategy can effectively strengthen the construction of teaching staff.

\subsection{Combining Compulsory and Optional Courses to Create a Distinctive Curriculum System}

From the findings of surveys of students' learning needs and social needs, it is obvious that class hours for language proficiency and translation skills should be increased, such as comprehensive English, English writing, translation, interpretation, etc. Besides, professional translators and interpreters should also be equipped with knowledge in the other subjects and translation is inherently interdisciplinary, so interdisciplinary optional courses should be offered to help cultivate the interdisciplinary awareness of students. Another advantage of optional courses is that students can study their chosen fields in depth according to their personal interests and employment needs. For example, for students who are interested in business translation, they can choose optional courses like international trade, international business, foreign etiquette and etc, for further in-depth study. Of course, when offering optional courses, universities should not only consider students' interest but also take the needs of local economic development and schools' academic advantages into account.

The establishment of a distinctive curriculum system is an important link in whether the professional translation talent training project can truly cultivate qualified talents. Being distinctive rather than comprehensive is more conducive to 
the training of market-oriented talents in universities. Therefore, each university can set up specialized courses such as news translation, legal translation, and business translation according to its own teachers and school conditions. Real translation projects could also be integrated with those specialized courses, making the curriculum vivid and practical. Qinghai is the source of Yellow River, Yangtze River and Lantsang, a famous cultural province and tourist attraction. Geographical science is also the trump card of Qinghai Normal University. It is feasible for the university to build distinctive courses like tourism translation after coordinating its advantages.

\section{Conclusion}

The aim of the study is to examine whether the current curriculum for students of translation and interpretation majors in Qinghai Normal University can meet both students' needs and social needs, proposing suggestions on curriculum design. The investigation of students' needs has shown that students' learning needs are satisfied to a large extent but they also expressed their expectations for the improvement of the current curriculum. Another significant finding to emerge from this study is that there is a gap between the current training of students of translation majors and the demand of employment market. Thus, greater efforts are needed to improve and reform the curriculum. Since the study was limited to the small sample size, the suggestions might not be feasible for schools in other regions. Further research could also be conducted to examine the effectiveness of curriculum design.

\section{Acknowledgements}

This work was supported by a grant of teaching reform research (No. 2019132) from the Qinghai Normal University, China.

\section{Conflicts of Interest}

The author declares no conflicts of interest regarding the publication of this paper.

\section{References}

Agrifoglio, M. (2004). Sight Translation and Interpreting: A Comparative Analysis of Constraints and Failures. Interpreting, 1, 43-67. https://doi.org/10.1075/intp.6.1.05agr

Beeby, A. (2000). Evaluating the Development of Translation Competence. In C. Schaffner \& B. Adab (Eds.), Developing Translating Competence (pp. 186-187). Amsterdam and Philadelphia: John Benjamins. https://doi.org/10.1075/btl.38.18bee

Chen, B. B. (2010). Theoretical Construction of College English Needs Analysis Model. Foreign Language Research, 2, 120-123.

Dudley-Evans, T., \& St John, M. J. (1998). Developments in English for Specific Purposes: A Multi-Disciplinary Approach. Cambridge: Cambridge University Press.

Hutchinson, T., \& Waters, A. (1987). English for Specific Purposes-A Learning-Centered Approach. Cambridge: Cambridge University Press. 


\section{https://doi.org/10.1017/CBO9780511733031}

Kiraly, D. (2000). A Social Constructivist Approach to Translator Education; Empowerment from Theory to Practice. Manchester: St. Jerome Publishing.

Li, H. X. (2010). A Study on the Translation Competence-Centered Curriculum Design for Translation Major. Foreign Language World, 2, 2-7.

Li, H. Y. (2018). The Training of Translation Professionals in the University of Ottawa and Its Enlightenment. Chinese Translators Journal, 39, 49-55.

Munby, J. (1978). Communicative Syllabus Design. Cambridge: Cambridge University Press.

Teng, M., \& Zhang, X. Y. (2013). Curriculum Design for MTI Program from the Perspective of Industrialization and Professionalism of Translation Industry. Shandong For eign Language Teaching, 4, 96-101.

Wang, C. Y. (2010). Development of the Localization Industry and Curriculum Innovation for MTI Program. Foreign Language Education, 31, 110-113.

Zhu, C. W., \& Yang, Z. T. (2019). Integrating CATTI with BTI Education: SISU's Model for Reforming the BTI Program. Chinese Translators Journal, 40, 75-81. 